\title{
1. ORGANIC GEOCHEMICAL ANALYSES OF CORE SAMPLES FROM SITE 362, WALVIS RIDGE, DSDP LEG 40
}

\author{
Jaap J. Boon, F.W. v.d. Meer, P.J.W. Schuyl, J.W. de Leeuw, and P.A. Schenck, \\ Delft University of Technology, Department of Chemistry and \\ Chemical Engineering, Organic Geochemistry Unit, Delft, The Netherlands \\ and \\ A.L. Burlingame, Space Sciences Laboratory, University of California, Berkeley
}

\begin{abstract}
Four core samples from Site 362 were selected for preliminary analysis. They were subjected to a wet low-temperature extraction, and their residues were treated with acid and base in order to release bound nonextractable fatty acids, hydroxy acids, and alcohols. The solvent extract was surveyed by means of Field Desorption Mass Spectrometry and separated into various classes of compounds by chromatographic techniques. Hydrocarbons, fatty acids, hydroxy acids, and alcohols were identified using capillary GC-MS. All samples show major contributions of terrigenous organic matter. Varying amounts of organic molecules derived from marine organisms and bacteria are present. Some specific compounds are evaluated with regard to diagenetic processes in the sediments.
\end{abstract}

\section{INTRODUCTION}

Site 362 is situated near the contact of the Walvis Ridge with the African continent. The cored sediments are marly nannofossil oozes and chalks. Four equally spaced samples ranging in age from Pleistocene to middle Miocene were selected for a preliminary organic geochemical survey.

The object of this study is to compare these samples with earlier studies of diatomaceous ooze in a Holocene marine biogenic deposit offshore of Walvis Bay (Southwest Africa) (Boon et al., 1975a, b, c) and to evaluate the contribution of terrigenous organic material during the Quaternary to sediments off Southwest Africa. The Pliocene and Miocene sediments are of interest because their organic matter, presumably partly terrigenous in view of the clay content of the sediments, was derived during different climatological circumstances than the Pleistocene sediments. (Ericson et al., 1963; Denton et al., 1971).

\section{EXPERIMENTAL}

\section{Sample Description and Extraction Procedure}

The samples were received frozen. Relevant data are summarized in Table 1, and the extraction procedure is shown in Figures 1 and 2.

The wet extraction procedure is based upon the ternary solvent system water-methanol-chloroform. From the wet weight (229 g for Section 13-4), about $10 \%$ was removed for elemental analyses. To the remaining wet sediment, $240 \mathrm{ml}$ of methanol were added. After sonication for $3 \mathrm{~min}$, the mixture was centrifuged and about $200 \mathrm{ml}$ of solvent was pipetted off. To the residue, $190 \mathrm{ml}$ of chloroform were added. After sonication and centrifugation, about $200 \mathrm{ml}$ of solvent were pipetted off. To the residue another $190 \mathrm{ml}$ of chloroform were added. After sonication and centrifugation about $200 \mathrm{ml}$ of solvent were pipetted off once again. The extracts were combined and concentrated to $2 \mathrm{ml}$ ("total extract"). Residual water was removed azeotropically with benzene. An aliquot was taken and evaporated to dryness in order to estimate the amount of total extract (Table 1). Over a period of $1 \mathrm{hr} 180 \mathrm{ml}$ of $6 \mathrm{~N} \mathrm{HCl}$ were added to the sediment residue stirring continuously. The sedimentwater mixture $(p \mathrm{H} 2)$ was extracted three times with 100 , 100 , and $60 \mathrm{ml}$ of chloroform, respectively, using sonication and centrifugation. The combined extracts were shaken with water in a separatory funnel. The chloroform layer was separated and evaporated to almost dryness ("acid-extract").

The sediment residue was refluxed in $100 \mathrm{ml}$ of $1.6 \mathrm{~N}$ $\mathrm{KOH}$ and $60 \mathrm{ml}$ of ethanol for $1 \mathrm{hr}$. After cooling the mixture was extracted twice with $100 \mathrm{ml}$ of ether using sonication and centrifugation. The combined extracts were washed with water in a separatory funnel until neutral. The ether extract was evaporated almost to dryness ("base-extract-neutrals"). The residue was acidified with $\mathrm{HCl}$ until $p \mathrm{H} \sim 2$ and extracted twice with $100 \mathrm{ml}$ of ether using sonication and centrifugation. The ether extracts were combined with the acidified water layer of the base-extract-neutrals in a separatory funnel. The ether layer was separated and washed with water until neutral. Finally the ether extract was evaporated to almost dryness ("baseextract-acids"). 
TABLE 1

Description of Samples From DSDP Leg 40 , Site $362^{\mathrm{a}}$

\begin{tabular}{|c|c|c|c|c|}
\hline Core-Section & $3-4$ & $13-4$ & $19-5$ & $29-4$ \\
\hline Depth $(\mathrm{m})$ & 62 & 157 & 263 & 453 \\
\hline Lithology & Diatom-Nanno-ooze & Diatom-Nanno-ooze & Marly Nanno-ooze & Marly Nanno-ooze \\
\hline Age & Pleistocene & Pliocene & Miocene & Miocene \\
\hline Sample (g wet weight) & 204 & 205 & 239 & 220 \\
\hline$\% \mathrm{H}_{2} \mathrm{O}$ & 52 & 39 & 37 & 27 \\
\hline Total extract (mg) & 298 & 173 & 90 & 62 \\
\hline$\% \mathrm{Ca}^{+2}$ & 14.89 & 19.47 & 23.48 & 21.47 \\
\hline$\% \mathrm{C}_{\text {tot }}$ & 8.51 & 8.17 & 8.23 & 6.64 \\
\hline$\% \mathrm{CO}_{3}-2$ & 16.45 & n.d. & n.d. & n.d. \\
\hline$\% \mathrm{H}$ & 0.88 & 0.73 & 0.43 & 0.47 \\
\hline$\% \mathrm{~N}$ & 0.38 & 0.23 & $<0.2$ & $<0.2$ \\
\hline
\end{tabular}

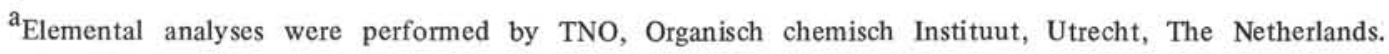

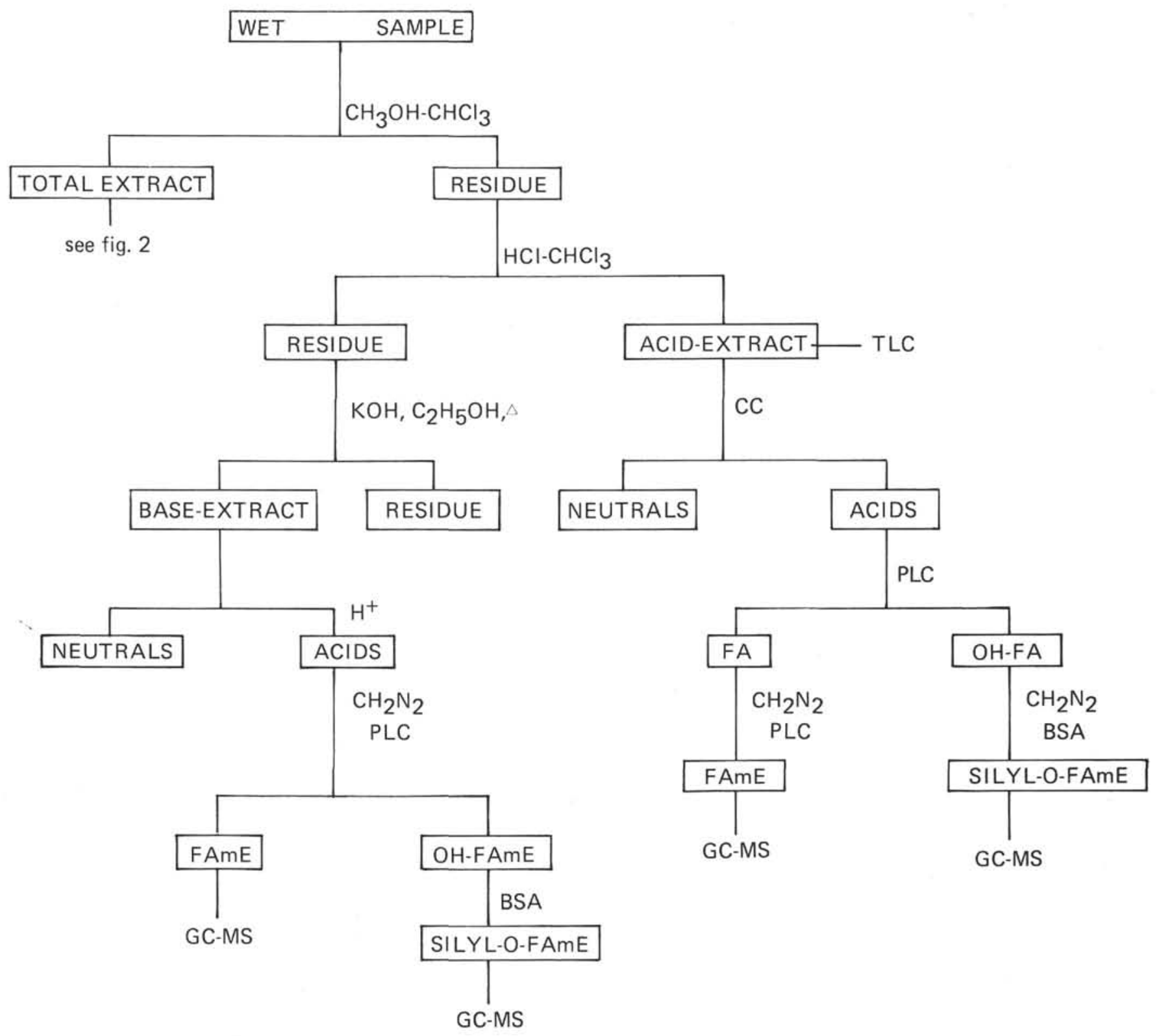

Figure 1. Extraction and isolation procedure. 


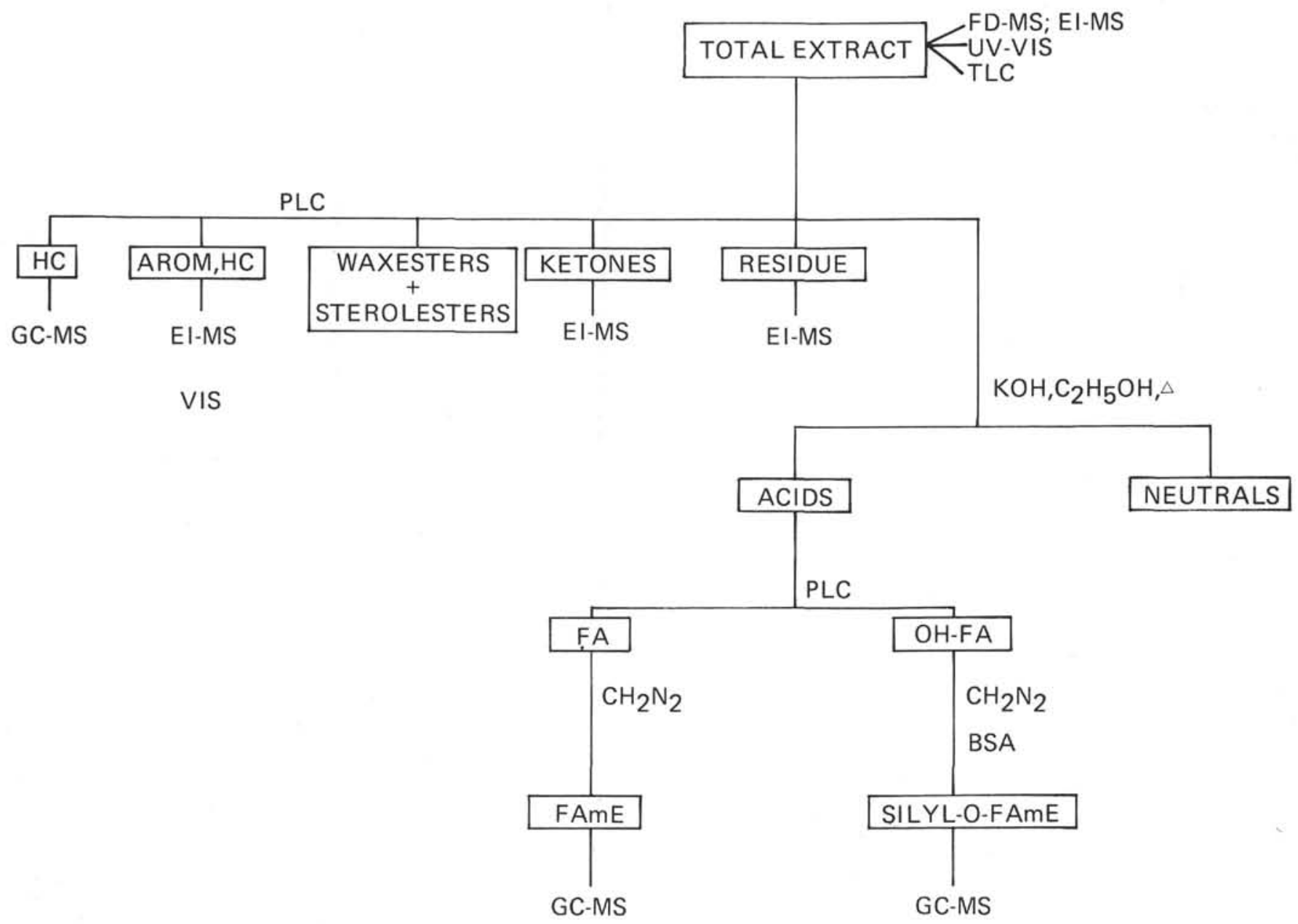

Figure 2. Extraction and isolation procedure of the total extract.

\section{Chromatographic Techniques}

The various extracts were examined by thin-layer chromatography (TLC) and separated into different fractions by means of preparative thin-layer chromatography (PLC) or column chromatography (CC) (Figures 1 and 2).

\section{Thin-layer Chromatography}

TLC plates $(0.25 \mathrm{~mm})$ were prepared with Kieselgel $\mathrm{G}$ (Merck, type 60). The plates were pre-eluted with chloroform/methanol $(1: 1 \mathrm{v} / \mathrm{v})$ and activated at $120^{\circ} \mathrm{C}$. Equal amounts of the total extracts were developed with diisopropylether/acetic acid $(96: 4 \mathrm{v} / \mathrm{v})$ up to $8 \mathrm{~cm}$ and redeveloped with petroleum ether 40$60 /$ ether/acetic acid $(89: 10: 1 \mathrm{v} / \mathrm{v})$. Detection of the spots was achieved by exposure to $\mathrm{I}_{2}$-vapor and by charring after spraying with $\mathrm{K}_{2} \mathrm{Cr}_{2} \mathrm{O}_{7}-\mathrm{H}_{2} \mathrm{SO}_{4}$-reagent (6 $\mathrm{g} \mathrm{K}_{2} \mathrm{Cr}_{2} \mathrm{O}_{7}$ in $1155 \% \mathrm{H}_{2} \mathrm{SO}_{4}$ ).

\section{Preparative Thin-Layer Chromatography}

PLC plates $(0.25 \mathrm{~mm}$ ) (Merck DC Fertigplatten Kieselgel 60) were pre-eluted with chloroform $/$ methanol $(1: 1 \mathrm{v} / \mathrm{v})$ and activated at $120^{\circ} \mathrm{C}$. The total extracts were separated by development with carbon tetrachloride.
The acid fractions obtained after base treatment of the total extracts were separated by development with ethyl/acetate/chloroform $(1: 1 \mathrm{v} / \mathrm{v})$ up to $6 \mathrm{~cm}$ and redevelopment with petroleum ether 40-60/ether/acetic acid $(89: 10: 1 \mathrm{v} / \mathrm{v})$.

The acid fractions obtained from the acid-extracts were separated in the same way. The methylated acid fractions obtained from the base-extracts were separated by development with diisopropylether/acetic acid $(96: 4 \mathrm{v} / \mathrm{v})$ up to $8 \mathrm{~cm}$ and redevelopment with petroleum ether 40-60/ether/acetic acid (89:10:1 v/v). Detection was achieved by exposure to $\mathrm{I}_{2}$-vapor and/or by spraying with $0.05 \%$ rhodamine $6 \mathrm{G}$ in $95 \%$ ethanol. Appropriate TLC bands were scraped off and extracted with hexane/ethyl/acetate.

\section{Column Chromatography}

The acid-extracts were separated into neutral and acid fractions by column chromatography on silicic acid impregnated with $\mathrm{KOH}$ /isopropanol as described by McCarty and Duthie (1962).

\section{Spectrometric Techniques}

\section{Mass Spectrometry}

Capillary GC-MS of the appropriate samples was performed on a Varian-MAT 111 instrument equipped 


\section{J. J. BOON ET AL.}

with a 30 meter OV 101 capillary column (i.d. 0.25 $\mathrm{mm})$; the gas chromatograph was temperature programmed from $120^{\circ}$ to $300^{\circ} \mathrm{C}$ at a rate of $4^{\circ} \mathrm{C} / \mathrm{min}$. Helium was used as carrier gas. Mass spectra were recorded at $80 \mathrm{eV}$. Field desorption mass spectrometry (FD-MS) of the total extracts was performed on a Varian-MAT $311 \mathrm{~A}$ instrument. Each sample was scanned from m/e 250 to 900 . The current through the tungsten wire was increased manually. In this way several scans at increasing temperature were obtained. Mass peaks of each scan representing more than 100 field ions were summarized; in this way an overall spectrum per sample was obtained (Figure 4).

Electron impact mass spectrometry (EI-MS) of the total extract of Section 13-4 and several fractions of this extract obtained after PLC separation was performed on a Varian-MAT $311 \mathrm{~A}$ instrument. Mass spectra were recorded at $70 \mathrm{eV}$. The probe temperature was increased at fixed intervals of $30^{\circ} \mathrm{C}$ from $70^{\circ}$ to $250^{\circ} \mathrm{C}$.

\section{Spectrophotometry}

Ultraviolet and visible spectra were obtained using a Hitachi Perkin-Elmer 124 double-beam spectrophotometer. The total extract from Section 3-4, 13-4, 19-5, and 29-4 was measured in chloroform. The visible spectrum of aromatic hydrocarbons from Section 13-4 (Figure 6) was measured in $n$-hexane.

\section{Modification Reactions}

Acids were esterified with diazomethane in ether. Alcohols and hydroxymethylesters were silyated in ethyl acetate with N,O-(bis)-trimethylsilylacetamide (BSA) at $60^{\circ} \mathrm{C}$ for $10 \mathrm{~min}$.

\section{Solvents, Reagents and Blanks}

The extraction and separation procedure was tested with blank runs. The blanks were searched for the compounds under investigation by means of FD-MS and GC-MS. Solvent stabilizers and some weakeners were observed, but none of the compounds identified in the extracts from the sediments were present.

\section{RESULTS}

In this preliminary study we planned to investigate hydrocarbons, fatty acids, and hydroxy acids. These compounds were selected for the potential information present in their molecular structure and their distribution (Ourisson, 1973; Kimble et al., 1974; Morris and Culkin, 1975; Boon et al., 1975a, b; de Leeuw et al., 1975).

The extraction procedure was focused on maximum efficiency of extraction and minimum formation of artifacts. Thus, a low temperature wet extraction procedure was used to avoid artificial polymerization, dehydration, and (inter) esterification reactions triggered by dehydrated clay surfaces (Arpino and Ourisson, 1971; de Leeuw et al., 1975).

The acid treatment applied to remove carbonate minerals from the sediment residue appeared to release entrapped and/or chemically bound organic matter. The final basic hydrolysis at elevated temperature was used to release covalent bound acidic and alcoholic moieties.

\section{Total Extract}

The various lipid classes in the total extracts of Sections 3-4, 13-4, 19-5, and 29-4 were surveyed in a semiquantitative way by means of TLC and FD-MS.

The $R f$ values of spots on the thin-layer chromatogram (Figure 3 ) indicate the presence of nonaromatic hydrocarbons, aromatic hydrocarbons, sterol esters and/or wax esters, ketones, acids, alcohols, sterols, and several pigments. A bright yellow spot with an $R f$ value corresponding to authentic $\beta$-carotene is observed in Sections 3-4 and 13-4 (trace amount).

A lemon-yellow spot with blue-green fluorescence at $350 \mathrm{~nm}$ and an $R f$ value corresponding to aromatic hydrocarbons is only observed in Section 13-4.

A large number of green-brown, red fluorescent spots with $R f$ values indicating a polar character are dominant in Section 3-4 and to some extent present in Section 13-4. Also in Section 3-4 is a strong absorption at $660 \mathrm{~nm}$ in the UV spectrum, indicative of chlorophyll derivatives, and this absorption decreases markedly in the other samples in order of their age. This phenomenon is accompanied by a strong increase of the absorption at $240 \mathrm{~nm}$, indicative of aromatic compounds. A strong absorption at $400 \mathrm{~nm}$ is present in all samples.

The molecular weight distribution ranging from $\mathrm{m} / \mathrm{e}$ 250-900 in the total extracts of Sections 3-4, 13-4, 19-5, and 29-4 was determined by means of FD-MS (Figure 4). The "fingerprints" obtained by this technique allow for comparison of the extracts and were helpful in the choice of the subsequent analytical procedure.

Interpretation of the observed peaks as molecular ions is hazardous. Often an $\left[\mathrm{M}^{+}+1\right]$ or $\left[\mathrm{M}^{+}-1\right]$ can be formed together with the $\left[\mathrm{M}^{+}\right]$, dependent on the kind of compound and sometimes fragmentation occurs.

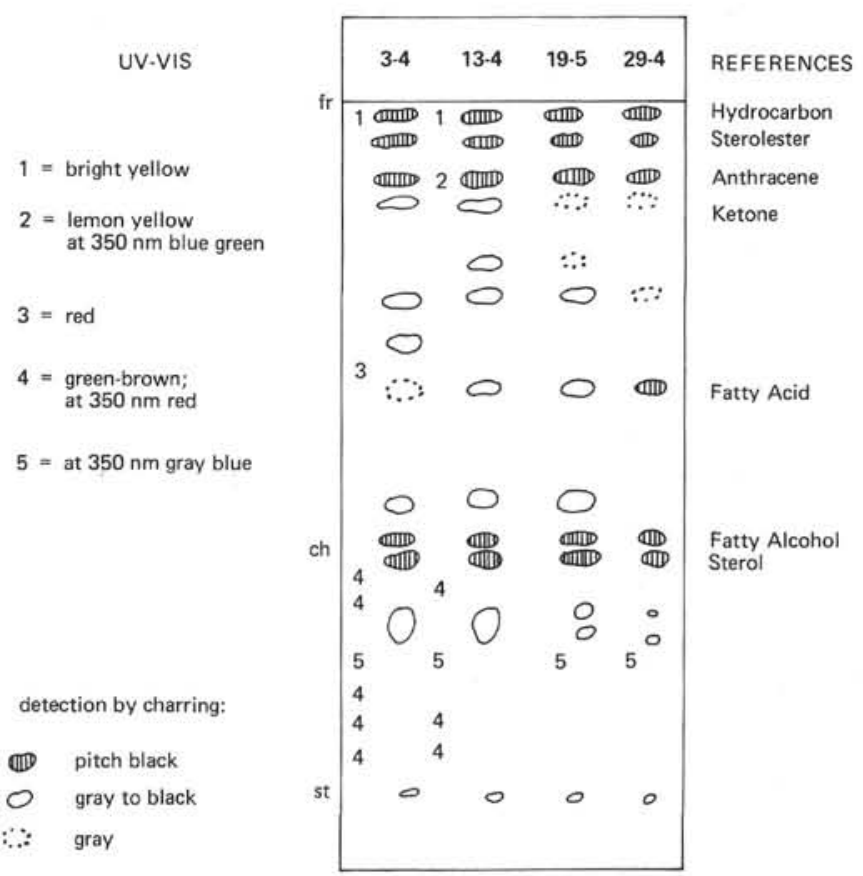

Figure 3. Thin-layer chromatogram of Sections 3-4, 13-4, 19-5, and 29-4. fr=front; $c h=$ change of eluants; $s t=$ start. 

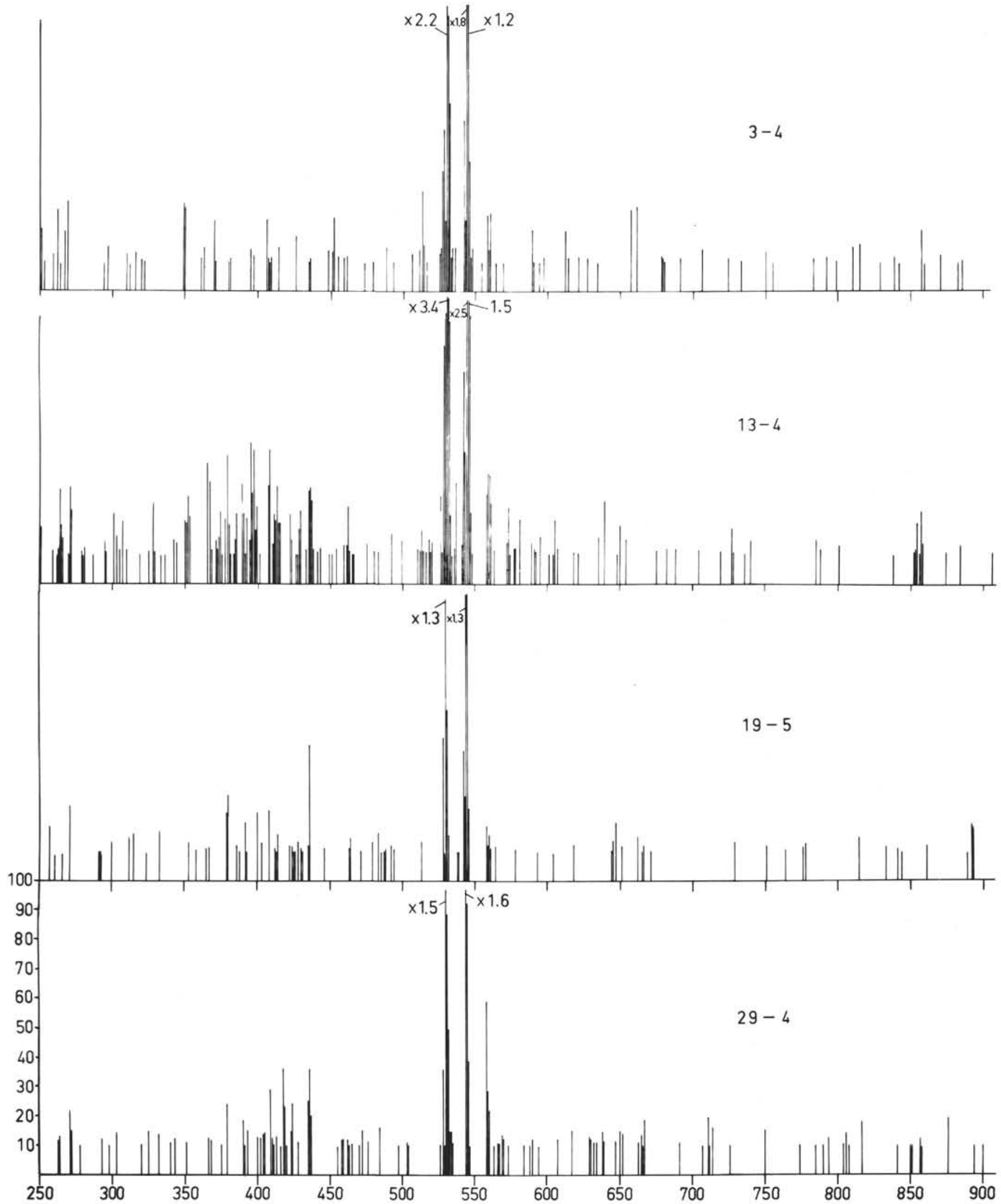

Figure 4. Field desorption mass spectrometric traces of Sections 3-4, 13-4, 19-5, and 29-4. 
Inspection of the FD-MS traces shows the overwhelming abundance of $\mathrm{m} / \mathrm{e} 530,544$, and 558. A remarkable difference between Section 13-4 and the other samples is the high intensity in the mass range m/e 350-450. This might correlate with a relative abundance of high molecular weight hydrocarbons e.g., $\mathrm{C}_{25}(\mathrm{~m} / \mathrm{e} 352)$, $\mathrm{C}_{27}(\mathrm{~m} / \mathrm{e} 380), \mathrm{C}_{29}(\mathrm{~m} / \mathrm{e} 408), \mathrm{C}_{31}(\mathrm{~m} / \mathrm{e} 436)$, steroidal (m/e 370-400), and triterpenoidal (m/e 400-440) structures in Section 13-4.

Based upon TLC and the UV-VIS spectra, we expected to find indications for chlorophyll derivatives and other porphyrin structures in the FD-MS traces. None of the peaks observed in the high mass range could be correlated with these structures, however. A study of the FD-MS behavior of authentic standards of these kinds of compounds is necessary before further conclusions can be drawn.

Peaks $\mathrm{m} / \mathrm{e} 536$ and $\mathrm{m} / \mathrm{e}$ 537, observed in Sections 3-4 and 13-4, are assigned to a $\beta$-carotene-type structure, earlier observed on TLC, because $\beta$-carotene shows an FD-MS spectrum consisting of $\mathrm{m} / \mathrm{e} 536\left[\mathrm{M}^{+}\right]$and $\mathrm{m} / \mathrm{e}$ $537\left[\mathrm{M}^{+}+1\right]$.

The assumed occurrence of several types of structures and individual components based upon TLC, UV-VIS, and FD-MS as survey methods provided a simplified view of the extracts, and defined the strategy for further analysis.

Thus aliquots of the total extracts were separated by preparative thin-layer chromatography to investigate the less polar lipids. We report on TLC bands with $R f$ values corresponding to saturated and unsaturated hydrocarbons, aromatic hydrocarbons, and ketones. Free and acyl-bound fatty acids present in the total extracts were investigated after basic hydrolysis of aliquots at elevated temperature.

\section{Nonaromatic Hydrocarbons}

Table 2 presents data on hydrocarbons as determined by capillary GC-MS. The GC-MS trace of Section 29-4 is shown as a typical example (Figure 5). A strong oddeven predominance is observed in all samples. No indications for the presence of pristane or phytane are found in the mass spectra.

A complex mixture of tetracyclic and pentacyclic compounds is found in all four hydrocarbon fractions; in Section 13-4 these compounds are abundant. A few of these compounds were identified from their mass spectra, which could be compared with those from literature data (Ensminger, 1974; Ageta, personal communication; Kimble et al., 1974). The relatively high amount of these compounds in Section 13-4 compared to the other samples is in agreement with speculations based on FD-MS traces.

\section{Aromatic Hydrocarbons}

Only the aromatic hydrocarbon fraction of Section 13-4 was characterized by its blue-green fluorescence on the TLC plate inspected in UV-light $(350 \mathrm{~nm})$. This fraction was investigated by EI-MS and UV-VIS. Major peaks in the UV-VIS spectrum (Figure 6) are similar to those of perylene (Aizenshtat, 1973). The high intensity of $\mathrm{m} / \mathrm{e} 252$ in the EI-mass spectrum supports this identification. In the same EI-mass spectrum a homologous series of peaks of high intensity is observed at $\mathrm{m} / \mathrm{e} 354+\mathrm{n} \times 14(n=0-8)$. Some of these peaks are also encountered in the FD-MS trace and are thought to be partly responsible for the "hump" in the mass area m/e 350-450.

The simultaneous occurrence of m/e 554 and $\mathrm{m} / \mathrm{e}$ 329 in the EI-mass spectrum might indicate the presence of $\mathrm{p}-(4,8,12$-trimethyltridecyl-1, 5, 9, 13tetramethyl tetradecyl) benzene, the postulated dimerization product of phytol derivatives (de Leeuw et al., 1975).

\section{"Peaks 530/544"}

The compounds responsible for the major peaks in the FD-MS traces, $\mathrm{m} / \mathrm{e} 530$ and $\mathrm{m} / \mathrm{e} 544$, were traced by EI-MS in a TLC band with an $R f$ value corresponding to ketones. Exact mass measurements revealed an elemental composition $\mathrm{C}_{37} \mathrm{H}_{70} \mathrm{O}$ for $\mathrm{m} / \mathrm{e}$ 530 and $\mathrm{C}_{38} \mathrm{H}_{72} \mathrm{O}$ for $\mathrm{m} / \mathrm{e} 544$.

\section{Fatty Acids and Hydroxy Acids}

Results of capillary GC-MS analysis of the methyl esters obtained from the corresponding fatty acids after base treatment of the total extracts, are presented in Table 3. The mass spectral fragmentation patterns of the compounds identified are in agreement with those of authentic standards and with data published by Ryhage and Stenhagen (1963), Douglas et al. (1971), and Boon et al. (1975b). Conspicuous characteristics of these fatty acids are: (1) exclusive presence of saturated straight chain acids; and (2) relative abundance of very long chain acids $\left(>\mathrm{C}_{20}\right)$ compared to long chain acids $\left(C_{12}-C_{20}\right)$. A search for hydroxy acids in Sections 3-4 and 13-4 proved to be negative.

\section{Acid-Extract}

The fatty acids and hydroxy acids obtained after acid treatment of the extracted sediment residues were analyzed by capillary GC-MS as their methyl esters and trimethylsilyloxy methyl esters, respectively. The data are presented in Tables 3 and 4 . Characteristic features of the fatty acids are: (1) The distribution of the very long chain fatty acids is completely different in the four

TABLE 2

Hydrocarbons Identified in Sections 3-4, 13-4, 19-5, and 29-4 DSDP Leg 40, Site 362

\begin{tabular}{cccl}
\hline $\begin{array}{c}\text { Core- } \\
\text { Section }\end{array}$ & $\begin{array}{c}\text { Range of } \\
n \text {-Alkanes }\end{array}$ & $\begin{array}{c}\text { Major } \\
\text { Component }\end{array}$ & \multicolumn{1}{c}{ Some Cyclic Hydrocarbons Identified } \\
\hline $3-4$ & $\mathrm{C}_{17}-\mathrm{C}_{33}$ & $n \mathrm{C}_{31}$ & Cholestane, 17(21)hopene, fernene, homohopane \\
$13-4$ & $\mathrm{C}_{17}-\mathrm{C}_{33}$ & $n \mathrm{C}_{31}$ & $17(21)$ hopene, fernene, homohopane \\
$19-5$ & $\mathrm{C}_{19}-\mathrm{C}_{33}$ & $n \mathrm{C}_{31}$ & $17(21)$ hopene, homohopane \\
$29-4$ & $\mathrm{C}_{17}-\mathrm{C}_{33}$ & $n \mathrm{C}_{31}$ & Cholestane, stigmastane, 17(21)hopene, homohopane \\
\hline
\end{tabular}




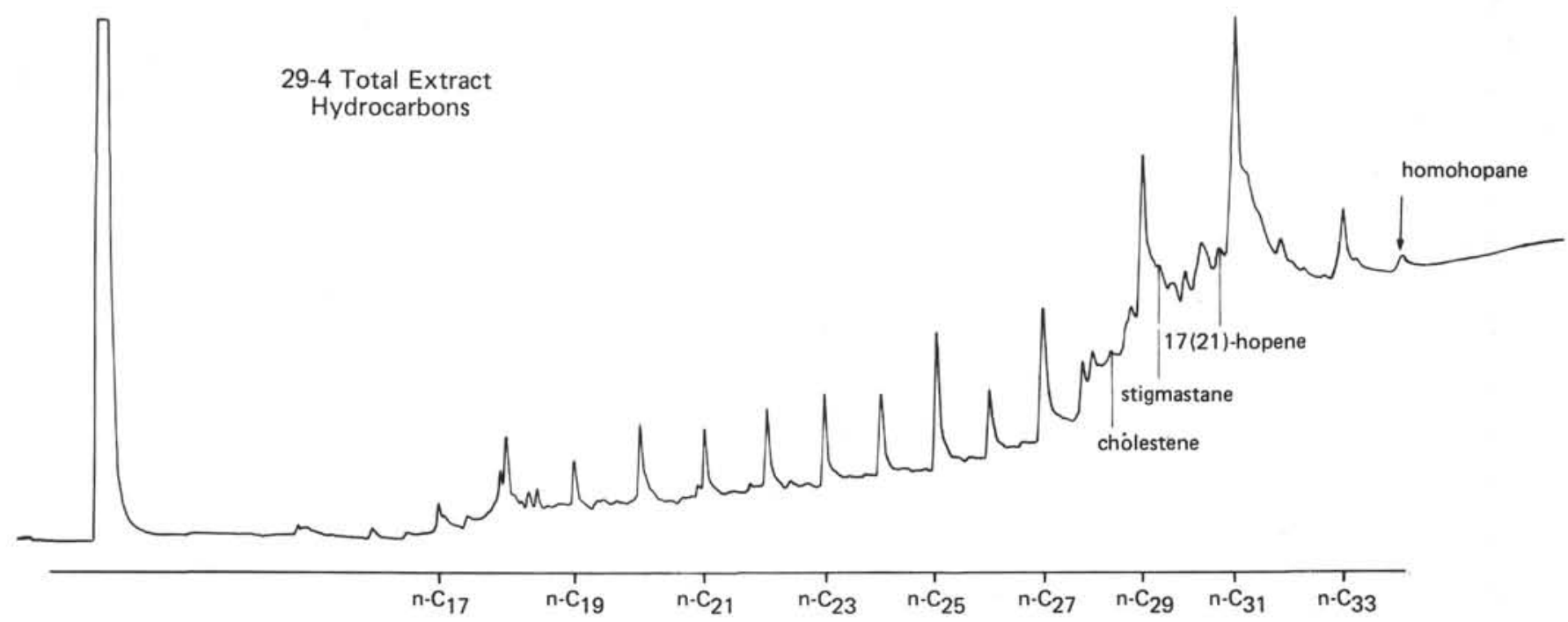

Figure 5. GC-MC trace of non-aromatic hydrocarbons of section 29-4. Conditions: see Experimental.

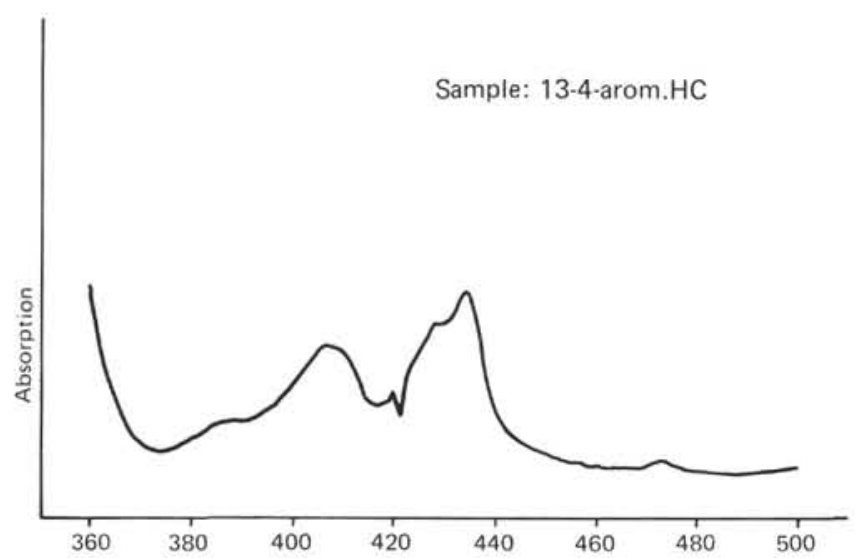

Figure 6. UV-VIS trace of aromatic hydrocarbons of secttion 13-4.

samples investigated: absence in Sections 3-4 and 29-4; abundant presence in Section 13-4. (2) Straight chain fatty acids are dominant. Iso, anteiso, and isoprenoid fatty acids are present in Sections 3-4, 13-4, and 19-5. (3) Mono-unsaturated long straight chain fatty acids ( $n$ $\left.\mathrm{C}_{16: 1, n} \mathrm{C}_{18: 1}\right)$ were found in all samples. Monounsaturated very long chain fatty acids ( $n \mathrm{C}_{24: 1}-n \mathrm{C}_{34: 1}$ are exclusively present in Section 13-4. (4) Phytenic acid (isopr $\mathrm{C}_{20: 1}$ ) is probably present in Section 13-4. Hydroxy acids were investigated in Sections 3-4 and 134. Some $\alpha$ - and $\beta$-hydroxy acids and one $\omega$-hydroxy acid were found only in Section 3-4.

\section{Base-extract}

Data on the fatty acids, alcohols, and hydroxy acids of the carbonate-free sediment residues are summarized in Tables 3, 4, and 5. Figure 7 presents the GC-MS trace of the fatty acids of Section $19-5$ as a typical example. The numbers correspond with compounds identified and listed in Table 3, column Base-extract19-5.

Characteristics of the fatty acids identified are: (1) Dominance of the long chain fatty acids $\left(\mathrm{C}_{12}-\mathrm{C}_{20}\right)$ in all samples. Section 3-4 is characterized by an extremely high relative amount of $n \mathrm{C}_{18: 0}$. (2) Iso, anteiso, and isoprenoid acids are present in all samples. The $\mathrm{C}_{14: 0}$, $C_{15: 0}, C_{16: 0}$, and $C_{17: 0}$ isoprenoid acids are relatively abundant.

Figure 8 shows a GC-MS trace of hydroxy acids and alcohols of Section 3-4. Alcohols and hydroxy methyl esters were identified as trimethylsilyloxy derivatives. Their mass spectra were compared with those of authentic standards and data of Eglinton and Hunneman (1968) and Brooks and Maxwell (1973).

The presence of alcohols in the hydroxy acid fraction is due to the analytical procedure used for the isolation of the hydroxy acids. Alcohols and hydroxy methyl esters are not separated in the TLC system used. Although the acid fraction of the Base-extract should not contain alcohols, their presence can be explained by assuming an incomplete wet extraction of the basic solution. The presence of the alcohols did not interfere with the hydroxy acid analysis. The presence of the alcohols in this fraction makes possible a preliminary survey of these compounds.

Characteristics of the hydroxy acids are: (1) An overwhelming presence of very long chain $\alpha$-hydroxy acids in Sections 3-4 and 19-5. (2) The presence of $\alpha$ hydroxy phytanic acid in Section 19-5. (3) Absence of hydroxy acids in Section 29-4.

The alcohols identified consist of a mixture of straight chain long and very long saturated alcohols. Phytol is abundant in Sections 3-4 and 13-4.

\section{DISCUSSION}

The four samples investigated exemplify a relatively abundant occurrence of organic molecules, attributable to allochthonous sources. This is substantiated by: (1) the strong odd/even predominance of the $n$-alkanes in the range $\mathrm{C}_{25}-\mathrm{C}_{33}$; (2) the abundant presence of tetracyclic and pentacyclic hydrocarbons; and (3) the relative abundance of very long chain saturated normal fatty acids.

A more detailed inspection of the organic molecules in the four samples allows for an evaluation of the 


\section{J. J. BOON ET AL.}

TABLE 3

Acids Identified in Sections 3-4, 13-4, 19-5 and 29-4 DSDP Leg 40, Site 362

Based Upon Capillary GC-MS Data

\begin{tabular}{|c|c|c|c|c|c|c|c|c|c|c|c|c|c|}
\hline \multirow[b]{2}{*}{ Compound } & \multicolumn{4}{|c|}{ Total Fistract } & \multicolumn{4}{|c|}{ Acid-Extract } & \multicolumn{5}{|c|}{ Base-Extract } \\
\hline & $3-4$ & $13-4$ & $19-5$ & $29-5$ & $3-4$ & $13-4$ & $19-5$ & 29.4 & $3-4$ & $13-4$ & $19-5$ & -5 & $29-4$ \\
\hline$n C_{10: 0}$ & & & & & & & & & & & +1 & & \\
\hline$n \mathrm{C}_{1.1: 0}$ & & & & & & & & & & & +2 & & \\
\hline$n \mathrm{C}_{12: 0}$ & & & & & & & & & + & & ++3 & & + \\
\hline isopr. $\mathrm{C}_{14: 0}$ & & & & & & & & & $\mathrm{tr}$ & & & & \\
\hline iso $C_{13: 0}$ & & & & & & & & & $\operatorname{tr}$ & & +4 & & \\
\hline a-iso $C_{13: 0}$ & & & & & & & & & & & +5 & & \\
\hline$n \mathrm{C}_{13: 0}$ & & & & & & & & & tr & & ++6 & & + \\
\hline isopr. $\mathrm{C}_{15: 0}$ & & & & & & & + & & $\mathrm{tr}$ & ++ & ++ & 7 & + \\
\hline iso $C_{14: 0}$ & & ++ & & & + & & & & $\operatorname{tr}$ & + & ++8 & 8 & + \\
\hline$n \mathrm{C}_{14: 0}$ & & +++ & & +++ & +++ & ++ & ++ & + & ++ & + & +++ & 9 & ++ \\
\hline iso $C_{15: 1}$ & & & & & & & & & $? \mathrm{tr}$ & & & & \\
\hline isopr. $\mathrm{C}_{16: 0}$ & & & & & & + & ++ & & + & ++ & ++ & 10 & ++ \\
\hline iso $C_{15: 0}$ & & & & & + & + & ++ & & + & + & ++1 & 11 & + \\
\hline a-iso $C_{15: 0}$ & & & & & ++ & + & ++ & & + & + & ++ & 12 & ++ \\
\hline$n \mathrm{C}_{15: 0}$ & & + & & ++ & ++ & + & ++ & & + & ++ & ++ & 13 & + \\
\hline isopr. $C_{17: 0}$ & & & & & & & + & & $? \mathrm{tr}$ & ++ & ++ & 14 & + \\
\hline iso $C_{16: 0}$ & & & & & + & ++ & + & & tr & + & ++ & 15 & + \\
\hline$n \mathrm{C}_{16: 1}$ & & & & + & & + & & & $\mathrm{tr}$ & & +1 & 16 & + \\
\hline$n \mathrm{C}_{16: 0}$ & +++ & +++ & ++ & $\underline{+++}$ & $\underline{+++}$ & +++ & +++ & +++ & +++ & $\underline{+++}$ & +++1 & 17 & +++ \\
\hline iso $C_{17: 0}$ & & & & & ++ & ++ & ++ & & + & + & ++1 & 18 & + \\
\hline isopr. $C_{19: 0}$ & & & & & + & + & & & & ++ & +1 & 19 & \\
\hline a-iso $C_{17: 0}$ & & & & & + & ++ & ++ & & + & ++ & ++ & 19 & ++ \\
\hline$n \mathrm{C}_{17: 0}$ & + & + & & ++ & ++ & ++ & ++ & & + & +++ & ++2 & 21 & ++ \\
\hline iso $\mathrm{C}_{18: 0}$ & & & & tr & + & + & + & & $\operatorname{tr}$ & & & & + \\
\hline$n \mathrm{C}_{18: 1}$ & & ++ & & +++ & ++ & ++ & ++ & +++ & + & ++ & ++2 & 22 & ++ \\
\hline$n \mathrm{C}_{18: 0}$ & +++ & +++ & + & +++ & +++ & +++ & +++ & ++ & +++ & $\pm+t$ & +++2 & 23 & +++ \\
\hline isopr. $\mathrm{C}_{20: 1}$ & & & & & & $?+$ & & & & & & & \\
\hline iso $C_{19: 0}$ & & & & & & ++ & ++ & & + & ++ & ++2 & 24 & \\
\hline$n \mathrm{C}_{19: 0}$ & & & & & & ++ & + & & + & ++ & ++ & 25 & \\
\hline iso $C_{20: 0}$ & & & & & & & + & & tr & & ++ & 26 & \\
\hline$n \mathrm{C}_{20: 0}$ & +++ & ++ & & + & & ++ & ++ & & + & ++ & +++ & 27 & ++ \\
\hline$n \mathrm{C}_{21: 0}$ & + & + & & & & + & ++ & & $\mathrm{tr}$ & + & ++ & 28 & tr \\
\hline$n \mathrm{C}_{22: 0}$ & +++ & +++ & ++ & ++ & & +++ & +++ & & ++ & +++ & +++ & 29 & ++ \\
\hline$n \mathrm{C}_{23: 0}$ & ++ & ++ & & & & ++ & ++ & & + & ++ & ++ & 30 & tr \\
\hline$n \mathrm{C}_{24: 1}$ & & & & & & + & & & $\operatorname{tr}$ & & tr & 31 & \\
\hline$n \mathrm{C}_{24: 0}$ & +++ & +++ & +++ & & & +++ & +++ & & ++ & +++ & +++ & 32 & + \\
\hline$n \mathrm{C}_{25: 0}$ & ++ & +++ & ++ & & & ++ & ++ & & + & ++ & ++3 & 33 & \\
\hline br $C_{26: 0}$ & & & & & & & + & & & & & & \\
\hline$n \mathrm{C}_{26: 1}$ & & & & & & ++ & & & $\mathrm{tr}$ & & & & \\
\hline$n \mathrm{C}_{26: 0}$ & $\underline{+++}$ & \pm++ & $\stackrel{+++}{ }$ & +++ & & $\underline{t++}$ & $\stackrel{+++}{+}$ & & ++ & +++ & +++ & 34 & ++ \\
\hline br $\mathrm{C}_{27: 0}$ & & & & & & + & + & & & & & & \\
\hline$n \mathrm{C}_{27: 1}$ & & & & & & + & & & & & & & \\
\hline$n \mathrm{C}_{27: 0}$ & ++ & ++ & +t & & & +++ & + & & + & ++ & ++3 & 35 & \\
\hline${ }^{n} \mathrm{C}_{28: 1}$ & & & & & & ++ & & & $\mathrm{tr}$ & & & & \\
\hline$n \mathrm{C}_{28: 0}$ & +++ & +++ & ++ & ++ & & +++ & +++ & & ++ & ++ & ++ & 36 & ++ \\
\hline br $C_{29: 0}$ & & & & & & + & & & tr & & & & \\
\hline$n \mathrm{C}_{29: 1}$ & & & & & & + & & & & & & & \\
\hline$n \mathrm{C}_{29: 0}$ & ++ & ++ & + & & & ++ & + & & + & & + & 37 & \\
\hline$n C_{30: 1}$ & & & & & & ++ & & & $\operatorname{tr}$ & & & & \\
\hline$n C_{30: 0}$ & +++ & +++ & ++ & ++ & & +++ & ++ & & + & & + & 38 & \\
\hline$n C_{31: 0}$ & & + & & & & ++ & + & & tr & & & & \\
\hline${ }_{n} \mathrm{C}_{32: 1}$ & & & & & & ++ & & & $\mathrm{tr}$ & & & & \\
\hline$n C_{32}: 0$ & & ++ & & & & ++ & ++ & & + & & & & \\
\hline$n C_{33: 0}$ & & & & & & + & $\mathrm{tr}$ & & $\mathrm{tr}$ & & & & \\
\hline$n \mathrm{C}_{34: 1}$ & & & & & & + & & & & & & & \\
\hline$n \mathrm{C}_{34: 0}$ & & & & & & ++ & + & & tr & & & & \\
\hline$n \mathrm{C}_{35: 0}$ & & & & & & & & & tr & & & & \\
\hline
\end{tabular}

Note: +++ : major peak: +++ : peaks with intensities ranging from $10-100 \%$ of major peak; $++:$ peaks with intensities ranging from $1-10 \%$ of major peak; +: peaks with intensities ranging from $0.1-1 \%$ of major peak; $t r$ : peaks with intensities less than $0.1 \%$ of major peak. ?: identification is uncertain. The numbers cited in Base-Extract-19-5 correspond with the numbers in Figure 7. 
TABLE 4

Hydroxy Acids in Sections 3-4, 13-4, 19-5, and 29-4 DSDP Leg 40, Site 362 Based Upon Capillary GC-MS Data

\begin{tabular}{|c|c|c|c|c|c|c|c|c|c|}
\hline & & tal ract & & $\begin{array}{l}\text { id- } \\
\text { ract }\end{array}$ & & & tase-Ex & & \\
\hline Compound & & $13-4$ & & $13-4$ & & 4 & 134 & $19-5$ & $19-4$ \\
\hline$\alpha-\mathrm{OH} n \mathrm{C}_{16: 0}$ & & & & & & & & ++ & \\
\hline$\alpha-\mathrm{OH} n \mathrm{C}_{17: 0}$ & & & & & & & & + & \\
\hline$\alpha-\mathrm{OH} n \mathrm{C}_{18: 0}$ & & & & & & 4 & & t+ & \\
\hline$\alpha-\mathrm{OH} n \mathrm{C}_{19: 0}$ & & & & & & & & ++ & \\
\hline$\alpha-\mathrm{OH} n \mathrm{C}_{20}: 0$ & & & & & ++ & 6 & & ++ & \\
\hline$\alpha-\mathrm{OH} n \mathrm{C}_{21: 0}$ & & & & & & & & & \\
\hline$\alpha-\mathrm{OH} n \mathrm{C}_{22}: 0$ & & & & & & +10 & & t+ & \\
\hline$\alpha-\mathrm{OH} n \mathrm{C}_{23: 0}$ & & & & & ++ & 12 & & & \\
\hline$\alpha-\mathrm{OH} n \mathrm{C}_{24: 0}$ & & & & & & +13 & \pm+ \pm & +H & \\
\hline$\alpha-\mathrm{OH} n \mathrm{C}_{25: 0}$ & & & & & & +15 & & t+ & \\
\hline$\alpha-\mathrm{OH} n \mathrm{C}_{26: 0}$ & & & \pm++ & & & \pm 16 & & \pm & \\
\hline$\alpha-\mathrm{OH} n \mathrm{C}_{27: 0}$ & & & & & & & & & \\
\hline$\alpha-\mathrm{OH} n \mathrm{C}_{28: 0}$ & & & ++ & & & +19 & & & \\
\hline$\alpha-\mathrm{OH} n \mathrm{C}_{29: 0}$ & & & & & & & & & \\
\hline$\alpha-\mathrm{OH} n \mathrm{C}_{30}: 0$ & & & & & & & & & \\
\hline$\alpha-\mathrm{OH}$ isopr. $\mathrm{C}_{20: 0}$ & & & & & & & & ++ & \\
\hline$\beta-\mathrm{OH} n \mathrm{C}_{26: 0}$ & & & +t & & $?+$ & & & & \\
\hline$\beta-\mathrm{OH} n \mathrm{C}_{28: 0}$ & & & + & & & 20 & & & \\
\hline$\omega=\mathrm{OH} n \mathrm{C}_{24}: 0$ & & & + & & & & & & \\
\hline
\end{tabular}
numbers in Figure 8.

TABLE 5

Alcohols Identified in Sections 3-4, 13-4, 19-5, and 29-4 DSDP Leg 40, Site 362 Based Upon Capillary GC-MS Data

\begin{tabular}{|c|c|c|c|c|}
\hline \multirow{2}{*}{ Compound } & \multicolumn{4}{|c|}{ Base-Extract } \\
\hline & $3-4$ & $13-4$ & $19-5$ & $29-4$ \\
\hline$n \mathrm{C}_{16: 0}$ & +1 & ++ & ++ & \\
\hline \multicolumn{5}{|l|}{$n \mathrm{C}_{17: 0}$} \\
\hline$n \mathrm{C}_{18: 0}$ & ++2 & + & ++ & +++ \\
\hline$n \mathrm{C}_{19: 0}$ & & + & ++ & ++ \\
\hline$n \mathrm{C}_{20: 0}$ & +5 & +++ & +++ & $\underline{+t+}$ \\
\hline$n \mathrm{C}_{21: 0}$ & & ++ & ++ & \\
\hline$n \mathrm{C}_{22: 0}$ & +++7 & $\underline{+++}$ & $\underline{+++}$ & ++ \\
\hline$n \mathrm{C}_{23: 0}$ & +9 & ++ & & \\
\hline$n \mathrm{C}_{24: 0}$ & +++11 & +++ & ++ & \\
\hline$n \mathrm{C}_{25: 0}$ & & + & & \\
\hline$n \mathrm{C}_{26: 0}$ & +++14 & +++ & + & \\
\hline \multicolumn{5}{|l|}{$n \mathrm{C}_{27: 0}$} \\
\hline$n \mathrm{C}_{28: 0}$ & ++17 & & & \\
\hline $\begin{array}{c}\text { isopr. } \mathrm{C}_{20: 1} \\
\text { (phytol) }\end{array}$ & $t++3$ & +++ & & \\
\hline
\end{tabular}

Note: See note Table 3. The numbers cited in Base-Extract-3-4 correspond with the numbers in Figure 8.

importance of the autochthonous organic matter either produced in the water column or in the sediment.

The contribution of bacterial organic matter is deduced from the abundance of iso-, anteiso-, and odd normal fatty acids ranging from $\mathrm{C}_{12}-\mathrm{C}_{20}$. The exclusive presence of bacterial acids in the extracts obtained after hydrolysis points to the fact that they are incorporated in the sediment in larger nonextractable structures, instead of being present as components of extractable lipid species, as is the case in living bacteria (Shaw, 1974; Boon et al., in preparation).
Major contributions of even fatty acids ranging from $\mathrm{C}_{12}-\mathrm{C}_{22}$ in some samples can be ascribed to a production in the marine environment by algae, zooplankton, etc. Based on these considerations we can conclude that Section 3-4 has the largest input of marine organic matter and Section 19-5 shows the largest influence of bacterial activity, while this activity is clearly demonstrated in Sections 3-4 and 13-4.

A striking detail in all extracts is the abundance of compounds with carbon chain lengths ranging from $\mathrm{C}_{20}$ $\mathrm{C}_{34}$ exemplified in fatty acids, $\alpha$-hydroxy acids, and alcohols. This suggests a common biochemical principle. The joint occurrence of these compounds in extracts obtained after hydrolysis indicates their presence in complex nonextractable lipid-like material. In this respect one could think of higher plant tissue or pollen walls with a protective function. This view is supported by the presence of very long chain compounds in sediments rich in higher plant material, deposited in salt marshes and swamps (Johnson and Calder, 1973; Cooper, 1971) and in peats (Given, 1975). Moreover very long chain $\alpha$-hydroxy acids have been found in seeds of higher plants (Pohl and Wagner, 1972).

Three peculiarities observed in Section 13-4 warrant additional discussion. Perylene-found only in this sample-is an indicator for terrigenous material deposited in a reduced environment (Aizenshtat, 1973). $p$-(4,8,12-trimethyltridecyl-1,5,9,13-tetramethyltetradecyl)-benzene in this sample is thought to be a dimerization product of phytol-derived phytadienes. Since a wet low temperature extraction was applied, artificial formation of this compound can be ruled out (deLeeuw et al., 1975). This finding confirms an earlier postulate for a well-defined diagenetic pathway of phytol (Simoneit et al., 1973) in sediments.

Phytol is still present as an alcohol moiety in Sections 3-4 and 13-4, as is deduced from its presence in the Base-extracts. The absence of bound phytol in the Miocene sections (19-5 and 29-4) indicates that this moiety has already been released.

Branched chain and unsaturated fatty acids ranging from $\mathrm{C}_{24}-\mathrm{C}_{32}$ have been found by Cooper (1971) in the swamp sediment of the Everglades (Florida). Their presence in Section 13-4 can be related to plant material produced in tropical wet lands during the Pliocene.

Although some data have been obtained concerning the compounds responsible for the overwhelming peaks $\mathrm{m} / \mathrm{e} 530$ and 544 , further separations and identifications are necessary to unravel the structures of these compounds. It is worthwhile mentioning that peaks of relatively high intensities are mentioned in this mass region in the mass spectra of Green River Shale extract by Gallegos (1971).

\section{ACKNOWLEDGEMENT}

Dr. G. Eglinton is thanked for transporting the samples from Berkeley (U.S.) to London airport. We thank Mr. P. Dullaart for drawing the pictures.

\section{REFERENCES}

Aizenshtat, Z., 1973. Perylene and its geochemical significance: Geochim. Cosmochim. Acta, v. 37, p. 559. 


\section{J. J. BOON ET AL.}

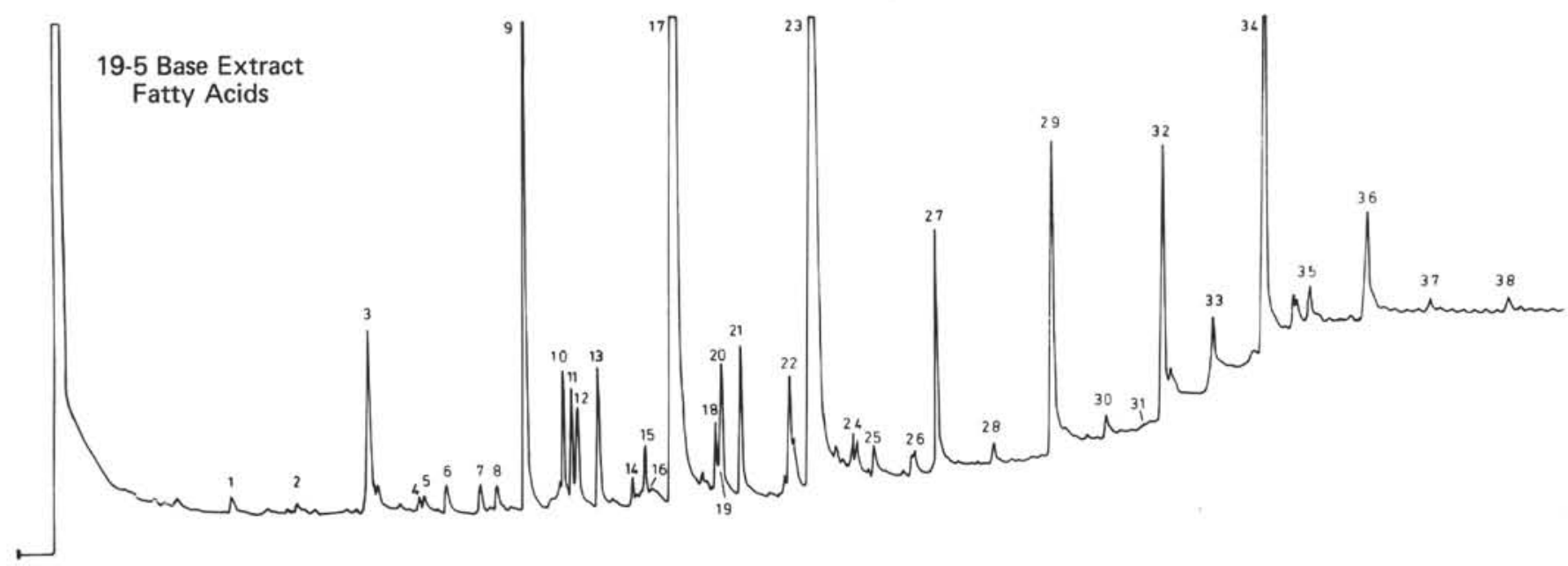

Figure 7. GC-MS trace of the methyl esters of Section 19-5-Base-Extract. Conditions: see Experimental. The peak numbers correspond with thise in Table 3.

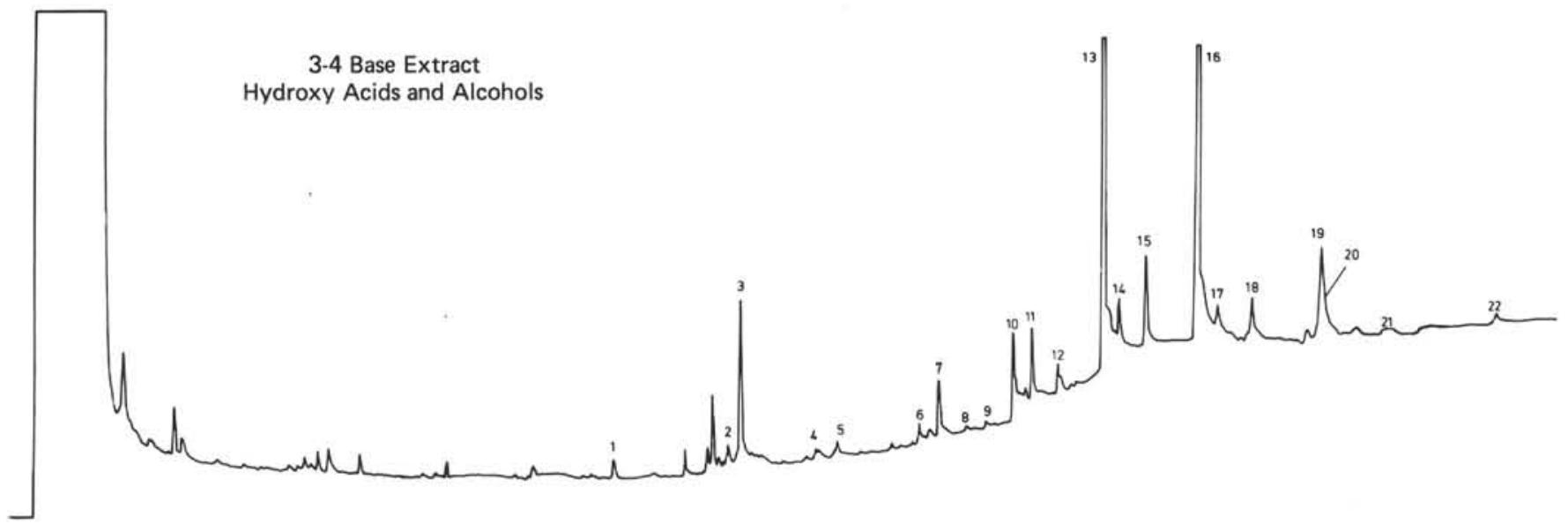

Figure 8. GC-MS trace of the trimethylsilyloxy methyl esters and trimethylsilyloxy alcohols of Section 3-4-Base-Extract. Conditions: see Experimental. The peak numbers correspond with those in Tables 4 and 5.

Arpino, P. and Ourisson, G., 1971. Interactions between rock and organic matter. Esterification and trans-esterification induced in sediments by methanol and ethanol: Anal. Chem., v. 43, p. 1656.

Boon, J.J., de Leeuw, J.W., and Schenck, P.A., 1975a. Organic geochemistry of Walvis Bay diatomaceous ooze-I. Occurrence and significance of fatty acids: Geochim. Cosmochim. Acta, v. 39, p. 1559.

Boon, J.J., de Lange, F., Schuyl, P.J.W., de Leeuw, J.W., and Schenck, P.A., 1975b. Organic geochemistry of Walvis Bay diatomaceous ooze-II. Occurrence and significance of the hydroxy fatty acids: Paper presented at the 7th Intern. Meeting on Organic Geochemistry, Madrid.

Boon, J.J., Rijpstra, W.I.C., de Leeuw, J.W., and Schenck, P.A., 1975c. Phytenic acid in sediments: Nature, v. 258, p. 414.

Boon, J.J., de Lange, F. Schuyl, P.J.W., de Leeuw, J.W., Schenck, P.A., Vosjan, J.H., and v.d. Hoek, G., in preparation. The occurrence and significance of iso and anteiso monoenoic fatty acids and branched chain $\beta$ hydroxy acids in Desulfovibrio desulfuricans.

Brooks, P.W. and Maxwell, J.R., 1973. Early stage fate of phytol in a recently-deposited Lacustrine sediment. In Tissot, B. and Bienner, F. (Eds.), Advance in organic geochemistry: Paris (Editions Technip), p. 977-991.
Cooper, W.J., 1971. Geochemistry of lipid components in peat-forming environments of the Florida Everglades: MS Thesis, The Pennsylvania State University, University Park, Pennsylvania.

de Leeuw, J.W., Simoneit, B.R., Boon, J.J., Rijpstra, W.I.C., de Lange, F., v.d. Leeden, J.C.W., Correia, V.A., Burlingame, A.L., and Schenck, P.A., 1975. Phytol derived compounds in the geosphere. Paper presented at the 7th Intern. Meeting on Organic Geochemistry, Madrid.

Denton, G.H., Amstrong, R.L., and Stuiver, M., 1971. The late Cenozoic glacial history of Antarctica. In Turekian, K.K. (Ed.), Late Cenozoic ice ages: New Haven (Yale University Press).

Douglas, A.G., Blumer, M., Eglinton, G., and DouraghiZadeh, K., 1971. Gas chromatographic-mass spectrometric characterization of naturally occurring acyclic isoprenoid carboxylic acids: Tetrahedron, v. 27, p. 1071.

Eglinton, G. and Hunneman, D.H., 1968. Gas chromatographic-mass spectrometric studies of long chain hydroxy acids-I: Phytochemistry, v. 7, p. 313.

Ensminger, A., 1974. Triterpénoides du schiste de Messel. Thèse, L'Université Louis Pasteur de Strasbourg, Strasbourg, France. 
Ericson, D.B., Ewing, M., and Wollin, G., 1963. PliocenePleistocene boundary in deep-sea sediments: Science, v. 139, p. 727.

Gallegos, E.J., 1971. Identification of new steranes, terpanes and branched paraffins in Green River shale by combined capillary gas chromatography and mass spectrometry: Anal. Chem., v. 43, p. 1151.

Given, P.H., 1975. Environmental organic chemistry of bogs, marshes and swamps. In Environmental chemistry, v. I: London (The Chemical Society), p. 70.

Johnson, R.W. and Calder, J.A., 1973. Early diagenesis of fatty acids and hydrocarbons in a salt marsh environment: Geochim. Cosmochim. Acta, v. 37, p. 1943.

Kimble, B.J., Maxwell, J.R., Philp, R.P., Eglinton, G., Albrecht, P., Ensminger, A., Arpino, P., and Ourisson, G., 1974. Tri- and tetraterpenoid hydrocarbons in the Messel oil shale: Geochim. Cosmochim. Acta, v. 38, p. 1165.

McCarty, R.D. and Duthie, A.H., 1962. A rapid quantitative method for the separation of free fatty acids from other lipids: J. Lipid. Res., v. 3, p. 117-120.

Morris, R.J. and Culkin, F., 1975. Environmental Organic Chemistry of Oceans, Fjords and Anoxic Basins. In
Environmental chemistry, v. I: London (The Chemical Society), p. 81-109.

Ourisson, G., 1973. Samsara of organic carbon: Pure. Appl. Chem., v. 33, p. 73.

Pohl, P. and Wagner, H., 1972. Fettsäuren in Pflanzen- und Tierreich (eine Übersicht) II. Trans-ungesättigte, Alkin-, Hydroxy-, Epoxy-, Oxo-, Cyclopropan und CyclopropenFettsäuren: Fette, Seifen, Anstrichmittel, v. 74, p. 541550.

Ryhage, R. and Stenhagen, E., 1963. Mass Spectrometry of long-chain esters. In McLafferty, F.W., (Ed.), Mass spectrometry of organic ions: New York (Academic Press), p. 399-453.

Shaw, N., 1974. Lipid composition as a guide to the classification of bacteria. In Perlman, D. (Ed.), Advanced applied microbiology, v 17: New York (Academic Press), p. 63108.

Simoneit, B.R., Glenn Howells, W., and Burlingame, A.L., 1973. Preliminary organic geochemical analyses of the Cariaco Trench, Site 147, Deep Sea Drilling Project, Leg 15. In Heezen, B.C., MacGregor, I.D., et al., Initial Reports of the Deep Sea Drilling Project, Volume 20: Washington (U.S. Government Printing Office), p. 907934. 